\title{
Just emotions: Reading the Sarah and Hagar narrative $($ Genesis 16, 21) through the lens of human dignity
}

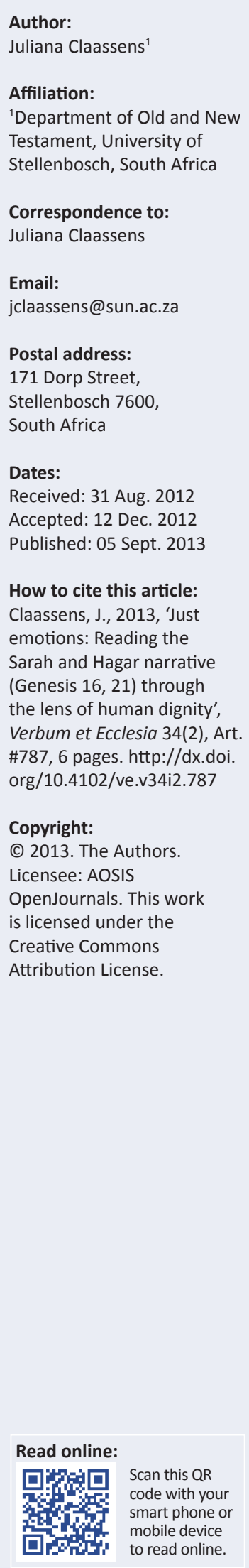

This article seeked to read the interconnected narratives of Sarah and Hagar (Genesis 16, 21) in terms of the hermeneutical lens of human dignity. For the purpose of this article, recent studies on the performative nature of emotions, which considered the central role of emotions such as pain, disgust and hatred in shaping the lives of individuals as well as the ways in which people relate to one another, were helpful in contemplating the situations of dehumanisation faced by both Sarah and Hagar as well as the broader question regarding upholding human worth in a context of indignity. This article furthermore considered the role of emotions in a conversation on ethics and particularly the way in which the narrative offered a fruitful avenue for considering Israel's relationship to their neighbours - a line of interpretation that holds potential for reflecting on complex interracial and interethnic relationships in today's global context.

\section{Introduction}

In recent years, the narrative of Sarah and Hagar as told in Genesis 16 and Genesis 21 has attracted quite a bit of attention. From feminist interpreters interested in bringing women's voices out from the shadows (Trible 1984:9-36; Sakenfeld 2003:7-26; Jeansonne 1990:14-30, 43-52) to womanist interpreters who have highlighted the unique role of Hagar's experience as a slave woman in order to denote the unique experiences of African American women (Williams 1993:15-33; Williams 2006:171-184; Weems 1988:1-22); all have provided fresh perspectives on this intriguing text. ${ }^{1}$ In a recent collection of essays, Hagar, Sarah, and their children, the rich interpretation history of this biblical narrative is documented when the authors trace the way Christian, Jewish and Islam interpreters respectively have claimed the story of Sarah and/or Hagar as their own (Trible \& Russell 2006). ${ }^{2}$

Indeed, the interconnected stories of Sarah and Hagar, which forms part of the Abraham narrative cycle, is a fascinating account that denotes the interaction between Israel and her neighbours. In light of the interesting developments in Old Testament ethics that consider the role of narrative, one could argue that the narrative of Sarah and Hagar, which clearly shows the humanity of its characters, serves as a powerful vehicle for moral reflection. ${ }^{3}$ In this regard, Martha Nussbaum (2001:243) describes the role of literature as 'a space with which we investigate and try out some of life's possibilities'. She argues that when entering a narrative world, 'the reader or spectator of a literary work is reading or watching the work but at the same time reading the world, and reading the own self' (Nussbaum 2001:243) Drawing on Marcel Proust's notion of literature as an 'optical instrument', Nussbaum (2001:243) argues that narrative may help the reader to contemplate personal realities, which, as will be evident in the case of Sarah and Hagar, may include some complex ethical issues. ${ }^{4}$

As part of a larger project on gender and human dignity, this essay seeks to read the interconnected narratives of Sarah and Hagar (Gn 16, 21) in terms of the hermeneutical lens of human dignity. For the purpose of this article, recent studies on the performative nature of emotions, that consider the central role of emotions such as pain, disgust and hatred in shaping the lives of individuals as well as the ways in which people relate to one another, are helpful in contemplating the situations of dehumanisation faced by both Sarah and Hagar as well as the broader question

1.For a good comparison of six of the most important feminist and womanist interpretations of the Hagar and Sarah stories see Weis (1996:253-273).

2.Cf. also Tikva Frymer-Kensky (2002:226) who demonstrates how various traditions claim this story as their own. So Sarah's name in Hebrew means 'princess', whereas in Islamitic tradition Hagar is not considered to be a slave but rather a princess married to Abraham. And in a Jewish Midrash, Hagar is viewed as a princess in the house of Pharaoh who after he had seen the wonders God performed for Abraham and Sarah thought it better for his daughter to be a servant in Abraham and Sarah's household than a princess in his own house.

3.For example, Barton (2003:60-63). See also Emmanuel Levinas's comment in Ethics and Infinity: 'It also appears in the Scriptures, to which the humanity of man is exposed inasmuch as it is engaged in the world' (p. 87, cited in Butler 2004:132)

4.Nussbaum (2001:243) argues as follow: 'Literary works, by contrast, show us general plausible patterns of actions, "things such as might happen" in human life. When we grasp the patterns of salience offered by the work, we are also grasping our own possibilities." 
regarding upholding human worth in a context of indignity. In light of Nussbaum's notion of narrative as 'an optical instrument', this article will consider the role of emotions in a conversation on ethics and particularly the way in which narrative serves as a means of 'show[ing] us the truth of our situation' (Nussbaum 2001:244). In this regard, the interconnected nature of the plight of these two women from different ethnic and social backgrounds indeed offers a fruitful avenue for considering Israel's relationship to their neighbours - a line of interpretation that holds a great deal of potential for reflecting on complex interracial and interethnic relationships in today's global context.

This article is dedicated to Prof. Jurie le Roux. I was privileged to have had him teaching a class on Wisdom Literature to our class at Stellenbosch University when I was a seminary student at the Faculty of Theology. I was shaped by Prof. Le Roux's passion for the Hebrew Bible as well as his ability to bridge the gap between the Old Testament and the contemporary context in which he had at that time been serving a congregation in Pretoria for more than 20 years. His ongoing presence in the field of Old Testament studies in South Africa, and particularly his commitment to the Pentateuch as evident in ProPent, has been an inspiration for my own work, including this current project on gender and human dignity in the biblical traditions.

\section{Narrating dehumanisation}

One key feature of the story of Sarah and Hagar is the way in which the wellbeing of both these female characters are threatened by forces that prevent them from flourishing, that is to reach their full potential. These forces cause the women much pain, each in her own way. In the case of Sarah, her situation of barrenness is shown to be a great threat to her status in a society that places great value on women's ability to bear children. ${ }^{5}$ And in the case of Hagar, being forced into a situation of limited or no resources during her expulsion into the wilderness is responsible for this Egyptian slave woman's anguish. ${ }^{6}$ In both instances, these two women's plight is portrayed as parallel as both women's ability to bear offspring is put into jeopardy - Sarah, due to her inability to conceive and Hagar, faced with the very real possibility of losing her son to hunger and thirst.

Remarkable about this narrative portrayal of indignity in the Sarah and Hagar narrative is the way in which the lives of these two women, who are portrayed as coming from different social and ethnic backgrounds, are interconnected, profoundly affecting one another. In order to explain their complex relationship, which serves as a fascinating means to contemplate not only the relationship between Israel and her neighbours but also on a contemporary level the interracial or interreligious relationships that are a key concern in many

5.Cf. Weems 1991:34. Katheryn Pfisterer Darr (1991:154) highlights the religious dimension associated with barrenness when she argues that 'Sarah lived for decades believing that God withheld children from her receiving constant reproach from her neighbours who wondered which sins were responsible for her infertility'.

6.Williams (1993:29) reads the wilderness experience in terms of the economic realities of poverty and homelessness. societies today, some helpful insights come from recent work done by feminist theorists on the role of emotions in shaping moral behaviour. So Sarah Ahmed (2004:194) considers the role of emotions such as fear, hate, disgust and pain within what she calls the 'contact zone' in which people of different racial or ethnic backgrounds are shaped and reshaped at the moment of encounter. Such interaction quite often occurs within the context of past encounters which have left their indelible mark on the relationship in addition to creating new associations that shape future contact.

In this regard, the narrative of Sarah and Hagar offers, as feminist and womanist scholars have suggested, a prime example of a contact zone denoting the interaction between racialised others, which, as so often happens in interracial relationships, evokes strong emotions of disgust and contempt. Actually the first reference to disgust in this narrative relates to Hagar, who is said, after she had conceived, to look with contempt [קלל] upon her mistress, or as the Tanakh translation has it, 'Her mistress was lowered in her esteem'. ' As her body grows heavy with child, Hagar regards her mistress Sarah as a 'lightweight'. Sarah responds to this slighting by afflicting Hagar - the Hebrew word ענה carrying distinct connotations of violence (Weems 1991:36). This term, which elsewhere is used to describe Israel's experience in bondage (Ex 1:11, 12; Dt 26:26), powerfully conveys Sarah's dehumanising actions toward Hagar. ${ }^{8}$ Sarah's irritation and sense of disgust is evident in Genesis 21:10 when Sarah complains to her husband about 'this slave woman', speaking in contempt and not even mentioning her name (cf. also Gn 16:5-6). That the power firmly lies in the hands of Sarah and Abraham though is evident from the fact that Abraham proceeds to tell his wife that Hagar is in her hand so that she can do with her whatever is good in her eyes (Gn 16:6). And in Genesis 21 we see how Sarah continues this abuse when she incites Abraham to banish Hagar and Ishmael to a life in the wilderness that may very likely have led to the demise of mother and child (v. 10).

It is evident from this account that the acts of contempt, violence and abuse have their roots in what appears to be a mutual sense of disgust. But what function does this emotion of disgust have in the Sarah and Hagar narrative and how does it help us in our ethical deliberation on the issues evoked by the interrelationship of these two women? The following aspects regarding the nature and function of emotions such as disgust and hatred are important for considering the way in which the dehumanisation of either or both women in this narrative is narrated.

\section{Emotions and ethics}

Firstly, it is remarkable that the lives of these women intersect at the very point at which Sarah is most vulnerable. Martha Nussbaum (2001) rightly has proposed that:

7.Cf. also Sarah's self-assessment of the situation when she says in Gn 16:5 that "I was slight in her eyes', which reflects her diminishing of status with referenced to Hagar (Trible 2006:39)

8.In this regard, Trible (2006:40) proposes that 'ironically, the verb depicts here the suffering of a lone Egyptian woman in Canaan, the land of her bondage to the Hebrews'. See also Darr (1991:13). Trible (1984:13) notes in her earlier essay on this Hebrews'. See also Darr (1991:13). Trible (1984:13) notes in her earlier essay on this
text that 'no deity comes to deliver her from bondage but instead she flees from her oppressor as Israel would later flee from Pharaoh'. 
the roots of anger, hatred, and disgust lie very deep in the structure of human life, in our ambivalent relation to our lack of control over objects and the helplessness of our own bodies. (p. 234)

In the case of Sarah, it is indeed her situation of barrenness that directly is responsible for causing a great deal of pain and suffering in the life of Hagar when she uses Hagar's body as a means to secure a baby for herself and her husband. When this plan does not quite work out, she afflicts Hagar. Moreover, after the wondrous occasion of the birth of her son, when Sarah sees Isaac playing (with Ishmael), she perceives Ishmael's presence to be a threat to her son. ${ }^{9}$ Ahmed (2004) says it well:

Such narratives work by generating a subject that is endangered by imagined others whose proximity threatens not only to take something away from the subject (jobs, security, wealth), but to take the place of the subject. The presence of this other is imagined as a threat to the object of love. (p. 43)

Ahmed (2004:43) continues that this perceived threat serves the function of transforming 'the bodies of others' 'into "the hated" through a discourse of pain'. The primary subject is construed as being injured or hurt by the presence of the other. ${ }^{10}$ This insight is particularly significant for how people in pain treat one another - personal and collective suffering often resulting in violence. ${ }^{11}$

Secondly, the emotion of disgust can be said to be profoundly ambivalent, encompassing at the same time a strong attraction toward the subject or object that is found to be repulsing (Ahmed 2004:84-85). Ahmed (2004) writes with reference to disgust's twin emotion hatred:

Where there is hate, there is obviously an excessive need for the object. In other words, hate is opposed to indifference: in hate, the object makes a difference, but cannot satisfy the subject, whose need goes beyond it. (p. 51)

In the story of Sarah and Hagar, it is clear that Sarah, due to her inability to bear children, needs Hagar and is drawn to her. But we also see the ambivalence at the heart of this desire when Sarah turns on Hagar in an expression of profound disgust.

Thirdly, the immediate effect of disgust is that it causes the subject to create distance between the self and the object or subject he or she finds disgusting. Ahmed (2004:94) writes

9.There is a certain ambiguity associated with this text as to what is transpirin between the two sons. Genesis 21:9 contains the ambiguous reading that Sarah saw Ishmael the son of Hagar 'playing' [מצחק]. The LXX inserts the object 'with Isaac' which is followed by the NRSV translation in order to clarify that Ishmael was Isaac' which is followed by the NRSV translation in order to clarify that Ishmael was
playing with Isaac (Frymer-Kensky 2002:234). Some commentators assert though playing with Isaac (Frymer-Kensky 2002:234). Some commentators assert though
that Ishmael did not play with Isaac but made fun of him. Or perhaps Ishmael is
playing Isaac, thus pretending to be the heir? See Trible's suggestion that Ishmael is 'Isaacing' (Trible 2006:44).

10.In her book, Ahmed (2004:27) considers the politics of pain, that is, what it is that pain does. As she argues: 'Pain is ... bound up with how we inhabit the world, how we live in relationship to surfaces, bodies and objects that make up our dwelling places'. Moreover, she considers 'how pain is involved in the production of uneven effects, in the sense that pain does not produce a homogenous group of bodies who are together in their pain' (p. 31).

11.Judith Butler (2004:28-29) characterises violence as follows: 'Violence is surely a touch of the worst order, a way a primary human vulnerability to other humans is exposed in its most terrifying way, a way in which we are given over, without is exposed in its most terrifying way, a way in which we are given over, without
control, to the will of another, a way in which life itself can be expunged by the wilful action of another'. that 'to abject something is literally to cast something out, or to expel something'. Employing the example of food that is found to be disgusting, a person would spit out an undesired object. On a social level, disgust may have a similar function, resulting in casting out or removing of an undesirable element. In the narrative of Sarah and Hagar, we see this vividly illustrated: firstly, Hagar removes herself from the situation of contempt when she runs away, and in the second instalment of the narrative, she is cast out or expelled by Sarah.

In this regard, emotions such as disgust and hatred are intrinsically involved in creating boundaries. Drawing on the work of Judith Butler, Sarah Ahmed (2004:12) argues that emotions such as disgust or hatred have an inherent world-making quality. It is by means of the repetition of these emotions that worlds are evoked, that identities are negotiated and that boundaries are fixed. ${ }^{12}$ She describes the effect of disgust as follows:

Disgust does something, certainly: through disgust, bodies 'recoil' from their proximity, as a proximity that is felt as nakedness or as an exposure on the skin surface. ... So disgust, even defined simply as bad taste, shows us how the boundaries that allow the distinction between subjects and objects are undone in the moment of their making. (Ahmed 2004:83)

In this regard, one finds in the Hebrew Bible ample evidence of the importance for Israel of drawing boundaries between themselves and the Canaanites who were to be found both inside and outside of Israel (Stone 2004:110-134; Runions 2011:53). For instance, Ken Stone (2005) has argued that the laws regarding food and sexuality exhibit a similar function, that is to draw clear boundaries between 'us' and 'them', in order to quell anxiety, fear and disgust that may emerge from any uncertainty about borders between these groups.

Fourthly, even though disgust or hatred is always directed at a particular person, this emotion is often transposed upon a group as a whole. ${ }^{13}$ With regard to the story of Sarah and Hagar one sees how the repeated reference to Hagar, the Egyptian, serves the function of sharply drawing the boundaries between Israel and one of her most significant neighbours. Tikva Frymer-Kensky (2002:232-233) has pointed out that this narrative of Sarah and Hagar ought to be read in the larger context of Israel's sojourn in Egypt where the roles of master or slave is dramatically reversed. ${ }^{14}$ It thus seems that the micro-story of Sarah's personal crisis of not being able to bear a child and her treatment of her servant

12.Ahmed (2004:12) formulates it as follows: "Feminist and queer scholars have shown us that emotions "matter" for politics: emotions show us how power shapes the very surface of bodies as well [as sic] worlds." See also Butler 1993:9.

13.Ahmed (2004:49) makes the important point that "hate may respond to the particular, but it tends to do so by aligning the particular with the general; "I hate you because you are this or that", where the "this" or "that" evokes a group that the individual comes to stand for or stand in for'.

14.Frymer-Kensky (2002:236) says it well: 'The story of Sarai and Hagar is not a story of the conflict between "us" and "other", but between "us" and "another us". Hagar is the type of Israel, she is the redeemed slave, she is "us".' See also Jeansonne (1990:28) who argues that Israel's genesis as a people is fragile and they continuously have been threatened by other nations - also by the children of they continuously have been threatened by other nations - also by the children of
Ishmael. But as she points out, 'yet the narrator does not portray this enemy of the people of Israel as an entity completely alien from themselves'. 
Hagar can be read on a macro-level of Israel contemplating their relationship with the Egyptians under whose hand they suffered serious affliction as narrated in the book of Exodus. So even though the Egyptian slave woman Hagar is the object of the scorn and contempt of her Israelite mistress Sarah, a couple of chapters later in Exodus 1, it will be the Israelites who find themselves in bondage. When the Egyptians are in a position of power and the Israelites are the slaves serving their harsh slave masters, it is evident that the Egyptians are greatly dependent on the Israelites to conduct their largescale building projects. But at the same time, they fear and are being repulsed by the Israelites - in its most extreme fashion leading to the genocide of the baby boys in Exodus 1.

It may well be that Israel's sojourn in Egypt is responsible for facilitating this contact zone between Israel and Egypt - a significant relationship that is equalled by Israel's tumultuous relationship with her neighbouring nations in Canaan. ${ }^{15}$ The narrative of Sarah and Hagar thus is situated in this ongoing process of identity negotiation that transpired against the backdrop of the affliction Israel experienced in Egypt but also the real and perceived threat of superpowers such as Babylon and Persia. ${ }^{16}$

Finally, Ahmed's notion of the 'stickiness' of signs (2004:92) is particularly helpful in explaining how emotions rely on stereotypes in order to fix the meaning of the other. She writes that emotions can become sticky, suggesting that a particular emotion may circulate around a subject, affixing itself to other concepts so that they become fused with the original concept. The example she employs relates to the term typically used in England, 'Paki' that through its use with other words such as 'immigrant', 'outsider', and 'dirty' has come to be viewed as a slur or an insult. This cumulative meaning generated by these signs being stuck together is responsible for the fact that the reference 'Paki' has obtained such secondary associations. ${ }^{17}$

With regard to the Hebrew Bible, Erin Runion (2011:49-51), who introduces these ideas of Ahmed on the stickiness of emotions into a Hebrew Bible context, argues that the Canaanite other quite often is associated with sexuality and immorality per se - the prostitute Rahab being a prime example. A similar tendency may be noted with reference to Hagar - her characterisation as exceptionally fertile may be associated with this notion of the Egyptian other being associated with hypersexuality. ${ }^{18}$ Actually, in the rabbinic interpretation of this narrative, one finds a fascinating

15.See Erin Runion's insightful essay (2011:45-74) on disgust and how it functions to draw boundaries between Israel and the Canaanite 'others' in her midst. See also Frymer-Kenski's view (2002:236) that for Israel other nations such as Moab, Amnon, Ishmael and Edom 'have destinies that are closely intertwined with Israel's.

16.See for example a recent volume on identity formation in the Persian Period that highlights the importance of maintaining boundaries, drawing sharp divisions between the returning exiles and the people of the land (Jonker 2011).

17.Ahmed (2004:92) writes: 'But it is not just surfaces that materialise through disgust. As one object is substituted for another, or moves into another, a border is temporarily affected, despite the fact that neither object is inherently disgusting. Such objects become sticky as an effect of this substitution.'

18.Darr (1991:134) cites a rabbinic interpretation that claims that Hagar became pregnant after only one sexual encounter. example of how Hagar as an Egyptian woman becomes associated with promiscuity. ${ }^{19}$ In an exposition on Hagar's act of taking an Egyptian wife for her son Ishmael (Gn 21:21), one finds in a tenth-century midrash on the book of Genesis, Aggadat Bereshit, the following connection between Hagar's fertility and her ethnic identity (based upon the preconceived notion in the Hebrew mind set as reflected in Ezekiel 23 that Egyptians are to be considered sexually promiscuous). In this midrash, Hagar is compared to the fat of a donkey, which will retain its odour even if one would pour rose oil on it:

Even though its smell became pleasant from the rose oil, it ended up stinking as it had before... The fat of a donkey is Hagar the Egyptian, as it says of the Egyptians (Ezk 23:20) 'whose members were like those of asses...' Hagar cleaved to Abraham and gave birth to Ishmael... but in the end she returned to her stench as it is written, 'And his mother took for him a woman from the land of Egypt' (Gn 21:21). (Cohen quoted in Reinhartz \& SimmaWalfish 2006:106)

This expression of disgust in terms of stereotypical ideas about the other also finds its way into the contemptuous way Israel is portrayed in Exodus 1. The remarkable growth of the Israelites is expressed by the narrator in his description of how the 'Israelites swarmed' ([שרץ] v. 7). Moreover, in verse 19 the midwives play into this dehumanising discourse when they tell the Pharaoh that the Israelite women are like animals - they give birth even before the midwives arrive. ${ }^{20}$ Ahmed (2004:46) points out with reference to such stereotypical designations that words like 'swarmed', 'flood' or 'swamped' generate effects: 'they create impressions of others as those who have invaded the space of the nation, threatening its existence'.

The expression of disgust in terms of such stereotypical notions may have the effect of blocking new meanings as such oft-repeated phrases are bound to bodies so that it obscures new meanings (Ahmed 2004:92). However, Ahmed (2004:64) notes that the very repetition of such stereotypes 'that is required to enable such a fixation renders them a site of insecurity rather than security'. She argues that 'such impossible truths become compelling precisely insofar as they might be lost on the way' (Ahmed 2004:64). Public discourse thus needs to keep these stereotypical ideas alive in order to maintain clear boundaries between 'us' and 'them'.

And yet, it may be possible to break through these stereotypes; for signs and emotions to become 'unstuck'. Runions (2011:54), who employs Ahmed's work on this matter, puts it well: ' ... [I]t seems to be that signs are never quite so static as they might appear. With some pushing and pulling, objects and affect can perhaps be unstuck and reconfigured'. In the next section, we will consider the possibilities already within the text for 'unsticking' the emotions of disgust and hatred

19.Ahmed (2004:44) writes: 'Note the work that is being done through this metonymic slide: mixed race couplings and immigration becomes readable as (like) forms of rape or molestation; an invasion of the body of the nation, evoked here as the rape or molestation; an invasion of the body of the nation, evol
vulnerable and damaged bodies of the white woman and child.'

20.Renita Weems (1992:32-33) argues that the racial differences and stereotypes assumed by this story are not challenged by the characters and/or the narrator.
assumes Rather the story simply inverts these stereotypes in order to serve its own Rather the story simply inverts these stereotypes in order to serve its own
ideological interests. Weems ends her essay with the question whether one can use this story for liberation, answering as follows: 'Not without due caution'. 
that feature so strongly in this text and thus resisting the dehumanisation narrated in the Sarah and Hagar narrative.

\section{Resisting dehumanisation}

Thus far we have seen how emotions such as disgust, hatred and pain work together to create a situation of dehumanisation experienced especially by Hagar in the Sarah and Hagar narrative. From being referred to as 'that slave women' instead of being called by her name, to being subjected to harsh treatment and abuse and finally being expelled from Abraham and Sarah's house, the biblical account vividly narrates the dehumanisation of this Egyptian slave girl. One would have expected that this narrative movement would finalise the removal of Hagar by writing her out of Israel's history. And yet, one is surprised by the continuing presence of Hagar in the text.

In this regard, some helpful perspectives come from the work of Judith Butler who, in her works Precarious Lives and Frames of War, argues that certain lives are considered by society to be more 'grievable' than others; more valuable and hence more worthy of protection (Butler 2004:32; cf. also Butler 2009). Writing in the aftermath of $9 / 11$, as well as the wars in Iraq and Afghanistan, Butler rightly considers the question who society chooses to remember. She asks: 'Who counts as human? Whose lives count as lives?'21 Conversely, within this hierarchy of grief, those who are considered less than fully human are susceptible to violence - of which perhaps the worst is the violence of derealisation. ${ }^{22}$ Butler continues to ask how one should think of this act of negation. She suggests that in society the dominant discourse has already done the work of dehumanisation (Butler 2004):

It is one thing to argue that first, on the level of discourse, certain lives are not considered lives at all, they cannot be humanized, that they fit no dominant frame for the human, and that their dehumanization occurs first, at this level, and that this level then gives rise to a physical violence that in some sense delivers the message of dehumanization that is already at work in the culture. ${ }^{23}$ (p. 36)

In contrast, Butler (2004:20) considers the important role of obituaries to document a life by revealing details of the person's life. She writes: 'It is a means by which life becomes, or fails to become, a publically grievable life, an icon for national self-recognition, the means by which a life becomes noteworthy' (Butler 2004:34).

21.Butler (2004:34) continues: "It is another thing to say that discourse effects violence though omission. If 200,000 Iraqi children were killed during the Gulf War and its aftermath, do we have an image, a frame for any of those lives, singly or collectively? Is there a story we might find about those deaths in the media? Are collectively? Is there a story we might find
there names attached to those children?'

22.Butler (2004:33) writes: 'What is real? Whose lives are real? How might reality be remade? Those who are unreal have, in a sense, already suffered the violence of derealisation. What, then, is the relation between violence and those lives considered as "unreal"?

23. Butler (2004:36) describes the effect of dehumanisation in discourse as follows: 'Dehumanization's relation to discourse is complex. It would be too simple to claim that violence simply implements what is already happening in discourse, such that a discourse on dehumanization produces treatment, including torture and murder,
structured by the discourse. Here the dehumanization emerges at the limits of structured by the discourse. Here the dehumanization emerges at the limits
discursive life, limits established through prohibition and foreclosure. There is less a dehumanizing discourse at work here than a refusal of discourse that produces dehumanization as a result. Violence against those who are already not quite living, that is, living in a state of suspension between life and death, leaves a mark that is no mark.'
In the case of the biblical account of Sarah and Hagar, it is quite significant that Hagar is not written out of Israel's history but that her suffering is remembered. The narrative told in Genesis 16 and 21 serves the important function of humanising Hagar and acknowledging her grief and loss. Hagar's presence in the text is all the more remarkable in light of Butler's point that society often effects violence through omission. Analogous to Butler's notion of the important role of obituaries, one sees in this biblical narrative an instance of how Hagar's suffering is recognised by God, who calls Hagar by name - Phyllis Trible (2006:40) rightly points out that Hagar is the first woman in the Hebrew Bible to receive an annunciation when God speaks to her and not, like the other characters thus far, about her. ${ }^{24}$ Hagar moreover becomes the only woman to receive the promise of a long line of descendants through her own destiny (Williams 1993:22; Frymer-Kenski 2002:230). ${ }^{25}$ Indeed God emerges as the 'God of seeing' (El Roeh) as Hagar in turn would name God, so constituting the first act of theologising in the Hebrew Bible (Trible 1984:18).

In some sense, Hagar's continuing presence in the text after she is expelled from the house of Abraham and Sarah serves as a type of memorial - some intimate details of Hagar's life are shared in the continuation of her narrative in Genesis 21 and so her life is cemented into Israel's consciousness. The reader observes in $\mathrm{v} 16$ how she alone in the wilderness raises her voice in lament, protesting her own plight as well as what this expulsion is about to do to her child. And after her eyes are opened and she sees the source of her salvation in the form of a well, providing life-sustaining water, the narrative divulges further details about the life the mother and son would make for themselves in the wilderness - a life that may be difficult in the harsh conditions of the wilderness, but a life lived in freedom (Frymer-Kenski 2002:236). ${ }^{26}$ It is significant that the last thing we see of Hagar is an act of agency on her part as she chooses an Egyptian wife for her son - so securing his (and her own) future.

These narrative details about Hagar and her life outside of Israel's purview have the function of breaking through the disgust in the narrative surrounding her ethnic identity and blocking new meanings. By means of her story, the Egyptian other is reconfigured to become a person in her own right the stereotypes attached to her body becoming unstuck. This process of rehumanisation is an ongoing process though. As we have mentioned before, in subsequent chapters, Israel will be the subject of dehumanising discourse and in need of resisting harmful stereotypes rooted in disgust.

24.The narrative is not devoid of complexity. So we see how God sends Hagar back to the house of slavery where she likely may suffer further affliction. Womanist scholar Delores Williams (1993:21) has read this particular narrative detail in terms of the theme of survival and quality of life - it was in the best interest of the mother and her unborn child to return to Abraham and Sarah's house and use the resources this dwelling has to offer.

25.God's promise to Hagar, though, about a future for her and her child is ambiguous when Hagar is promised that her son will be 'a wild ass of a man', suggesting a mixture of freedom and self-determination, but also foreshadowing continuing mixture of freedom and self-determination,
strife between Ishmael and his neighbours.

26.Weems (1988:15) suggests that perhaps it is better that Hagar and Ishmael left in order to be able to stand on their own feet. 


\section{Conclusion}

As stated in the beginning of the essay the narrative of Sarah and Hagar has the potential to serve as a space for contemplating complex ethical issues arising from the interaction that continues to occur between interracial and/ or interreligious relationships. The story of Sarah and Hagar is not a happy one though - the relationship between the two women disintegrates completely and ends with the expulsion of Hagar. But as Martha Nussbaum (2001:244) has proposed, 'painful literary experiences', which confirm that we are 'needy and limited creature[s]', are helpful in that they may assist us in reaching a greater understanding of ourselves as well as of others.

One example comes from the work of Elie Wiesel (1986:248249) who in an exposition on 'Ishmael and Hagar' blames Sarah who, in his mind, could have done better by loving both Isaac and Ishmael. He laments: 'If only she could have brought them together instead of setting them apart! Maybe some of today's tragedies would have been avoided'. In this quote Wiesel refers to the Palestinian crisis that, according to him, has its roots in the separation of brothers. One could add though numerous instances of interracial, interethnic and interreligious strife that mar our world today - of particular significance for us in South Africa with our complex and still often painful race relations. ${ }^{27}$

The story of Sarah and Hagar thus may help us contemplate the effect of disgust on the bodies involved in the contact zone. As Martha Nussbaum (2001:299) has argued, disgust is the enemy of compassion. She argues that in a society's pursuit for justice, which is closely associated with the obligation to cultivate compassion in its people, 'the impediments to compassion's ethical work' is 'supplied by shame, resentment, envy, and disgust'. We have moreover seen how disgust can block new meanings, being responsible for stereotypical notions that taint the relationship between racialised others. And in its most extreme manifestation of disgust, certain bodies may become fixed as objects of hate which may result in their destruction in what is known as hate crimes (Ahmed 2004:57, 60).

The Sarah and Hagar narrative implores the reader not to ignore the injustice done to those who literature (and society) deem disgusting or unfit. For as Ahmed (2004:57) warns us: 'To allow such bodies to disappear in our own analysis would be to repeat the crime rather than to redress its injustice'. As biblical interpreters we are called to redress injustice and lift up interpretations that may restore the dignity of men, women and children scarred in situations of dehumanisation.

27.Darr (1991:152-155), who cites Wiesel, questions the idea that the woman receives all the blame for the shortcomings of an inherently unjust patriarchal society. See also Weems (1988:2), who argues that it is not fair to make the story of Sarah and Hagar 'carry all the weight of the history of race relationships in the modern world'. Nevertheless, Weems highlights the role economic injustice plays in exacerbating the racial prejudice that already exists between these women who are co-victims in a patriarchal society.

\section{Acknowledgements Competing interests}

The author declares that she has no financial or personal relationship(s) that may have inappropriately influenced her in writing this article.

\section{References}

Ahmed, S., 2004, The cultural politics of emotion, Edinburgh University Press, Edinburgh.

Barton, J., 2003, Understanding Old Testament ethics: Approaches and explorations, Westminster John Knox, Louisville, KY.

Butler, J., 1993, Bodies that matter: On the discursive limits of 'sex', Routledge, New York, NY.

Butler, J., 2004, Precarious life: The powers of mourning and violence, Verso, London.

Butler, J., 2009, Frames of war: When is life grievable?, Verso, London.

Cohen, M. (ed.), 1997, Mikraot Gedolot HaKeter, Bar llan Press, Ramat Gan.

Darr, K.P., 1991, 'More than a possession: Critical, rabbinical, and feminist perspectives on Hagar', in K. Darr, Far more precious than jewels: Perspectives on biblical women, pp. 132-163, Westminster John Knox, Louisville, KY.

Frymer-Kensky, T., 2002, 'Hagar, my other, my self', in T. Frymer-Kensky, Reading the women of the Bible: A new interpretation of their stories, pp. 225-237, Schocken Books, New York, NY.

Jeansonne, S.P., 1990, The women of Genesis: From Sarah to Potiphar's wife, Fortress Press, Minneapolis, MN.

Jonker, L. (ed.), 2011, Texts, contexts and readings in postexilic literature, Mohr Siebeck, Tübingen.

Nussbaum, M.C., 2001, Upheavals of thought: The intelligence of emotions, Cambridge University Press, Cambridge. http://dx.doi.org/10.1017/СBO9780511840715

Reinhartz, A. \& Simma-Walfish, M., 2006, 'Conflict and coexistence in Jewish interpretation', in P. Trible \& L.M. Russell (eds.), Hagar, Sarah, and their children: Jewish, Christian, and Muslim perspectives, pp. 101-126, Westminster John Knox, Louisville, KY

Runions, E., 2011, 'From disgust to humor: Rahab's queer affect', in T.J. Hornsby \& K. Stone (eds.), Bible trouble: Queer reading at the boundaries of biblical scholarship, Semeia Studies 67, pp. 45-74, Society of Biblical Literature, Atlanta, GA.

Sakenfeld, K.D., 2003, Just wives: Stories of power and survival in the Old Testament and today, Westminster John Knox, Louisville, KY.

Stone, K., 2004, 'Queering the Canaanite', in M. Althaus-Reid \& L. Isherwood (eds.), Sexual theologian: Essays on sex, God and politics, pp. 110-134, T\&T Clark, London.

Stone, K., 2005, Practicing safer texts: Food, sex and Bible in queer perspective, Continuum, Sheffield.

Trible, P., 1984, 'Hagar: The desolation of rejection', in P. Trible, Texts of terror: Literary feminist readings of biblical narratives, pp. 9-36, Fortress Press, Philadelphia, PA.

Trible, P., 2006, 'Ominous beginnings for a promise of blessing', in P. Trible \& L.M. Russell (eds.), Hagar, Sarah, and their children: Jewish, Christian, and Muslim perspectives, pp. 33-70, Westminster John Knox, Louisville, KY.

Trible, P. \& Russell, L.M. (eds.), 2006, Hagar, Sarah, and their children: Jewish, Christian, and Muslim perspectives, Westminster John Knox, Louisville, KY.

Weems, R.J., 1988, 'A mistress, a maid, and no mercy', in R. Weems, Just a sister away: A womanist vision of women's relationships in the Bible, pp. 1-22, LuraMedia, San Diego, CA

Weems, R.J., 1991, 'Do you see what I see: Diversity in interpretation', Church and Society $82,28-43$.

Weems, R.J., 1992, 'The Hebrew women are not like the Egyptian women: The ideology of race, gender and sexual reproduction in Exodus 1 ', in D. Jobling \& $T$. Pippin (eds.), Ideological criticism of biblical texts: Semeia 59, 25-34.

Weis, R.D., 1996, 'Stained glass window, kaleidoscope or catalyst: The implications of difference in readings of the Hagar and Sarah stories', in R.D. Weis \& D.M. Carr (eds.), Journal for the Study of the Old Testament, suppl. ser. 225.

Wiesel, E., 1986, 'Ishmael and Hagar', in J.A. Edelheit (ed.), The life of covenant: The challenge of contemporary Judaism: Essays in honor of Herman E. Schaalman, pp. 235-249, Spertus College of Judaica Press, Chicago, IL.

Williams, D., 1993, 'Hagar's story: A route to black women's issues', in D. Williams, Sisters in the wilderness: The challenge of womanist God-talk, pp. 15-33, Orbis Books, Maryknoll, NY.

Williams, D., 2006, 'Hagar in African-American appropriation', in P. Trible \& L.M. Russell (eds.), Hagar, Sarah, and their children: Jewish, Christian, and Muslim perspectives, pp. 171-184, Westminster John Knox, Louisville, KY. PMCid:3454961 